\title{
Imigranti ve školním vzdělávání v Německu, Velké Británii a Švédsku
}

\author{
Immigrants in educational system in Germany, Great Britain and Sweden
}

Věra Ježková

\begin{abstract}
Abstrakt: V př́ispěvku představujeme část výsledků srovnávací analýzy zaměřené na školní vzdělávání v Německu, Velké Británii a Švédsku, a to problematiku imigrantů. Ukazujeme, jak jsou integrováni do škol daných zemí a jak je řešena jejich jazyková podpora. Téma zařazujeme do společensko-politického kontextu imigrace. Docházíme k závěru, že mezi sledovanými zeměmi neexistují žádné zásadní rozdíly.
\end{abstract}

Klíčová slova: školní vzdělávání, imigranti, integrace, jazyková podpora

\begin{abstract}
The paper presents a part of the results of the comparative analysis of educational system in Germany, Great Britain and Sweden concerning the problem of immigrants. The paper deals with immigrant school integration and organization of their language support. The topic is related to the social - political context of immigration. The conclusion is that there is no important difference between the three countries.
\end{abstract}

Keywords: educational system, immigrants, integration, language support

\section{1 Úvod}

Ve své stati představujeme vybrané výsledky řešení dílčího cíle 2 , který byl součástí projektu řešeného v Ústavu výzkumu a rozvoje vzdělávání PedF UK v letech 2006-2010, a to projektu MŠMT Centrum základního výzkumu školního vzdělávání. Hlavním záměrem daného cíle bylo vypracovat analyticko-srovnávací studie o vzdělávacích systémech v Německu, ve Švédsku a Velké Británii. V Nakladatelství Karolinum byly dosud publikovány studie Školní vzdělávání v Německu (2008) a Školní vzdělávání ve Velké Británii (2009). Studie o školním vzdělávání ve Švédsku je v tisku. Metodologii zpracování analyticko-srovnávací studie jsme představili na konferenci ČAPV v roce 2009. Téma stati jsme zvolili proto, že je stále více aktuální i v českém školním vzdělávání. Z důvodu limitovaného rozsahu však komparaci se situací v České republice neuvádíme.

\section{Společensko-politický kontext imigrace}

Všechny sledované země zažívají od poloviny minulého století výrazný př́liv imigrantů. Imigranti tvoří v současné době více než 19 \% veškerého obyvatelstva Německa (Statistisches Bundesamt...). Největší skupinou cizinců jsou Turci. Německo potřebovalo dlouhou dobu na to, aby začalo reagovat konstruktivně na skutečnost, že se stává zemí přistěhovalců. Původně počítalo s tím, že většina imigrantů se vrátí po čase do své vlasti. Pro rodiny imigrantů je mimořádně těžké postoupit na sociálním žebříčku nebo si zlepšit svoji ekonomickou situaci. V uplynulých dvou desetiletích však dosáhlo Německo „,v integraci imigrantů značných 
pokroků. Např. bylo zákonem usnadněno získání německé státní př́íslušnosti, posílily se kontakty mezi imigranty a Němci a vzrostla schopnost domácího obyvatelstva akceptovat etnickou a kulturní různorodost“" (Ježková, von Kopp, \& Janík, 2008, s. 110).

Velká Británie je výrazně multikulturní země. Nebělošská etnika tvoří přibližně $8 \%$ obyvatel. Největší skupinu přistěhovalců z jedné země představují Indové. K nejvíce vydělávajícím a nejvíce vzdělaným obyvatelům patří Č́iňané. Občané Velké Británie přiznávají určité obavy z rostoucí multikulturality své společnosti, nedůvěru k imigrantům. Řada místních obyvatel se obává toho, že jejich sousedé neovládají dostatečně angličtinu (Community Cohesion..., 2007/08).

Ve Švédsku tvoří imigranti přibližně $12 \%$ obyvatelstva. Nejpočetnější skupiny přistěhovalců jsou Íránci, Kurdové, Chilané a lidé z východní a jižní Afriky (Švédsko..., 2010). Pro Švédsko byla dřive charakteristická liberální přistěhovalecká politika. V poslední době se však postoj domácího obyvatelstva k imigrantům mění, zejména kvůli obavám o pracovní místa a kvůli rasovým nepokojům, které imigranti vyvolávají především kvůli své špatné ekonomické situaci (Protiimigrační strana..., 2010). V současné době se domnívají 54 \% Švédů, že země přijala př́lišs mnoho přistěhovalců (Švédsko..., 2010). Změnu postojů společnosti k přistěhovalcům potvrdily i parlamentní volby v září 2010, v nichž se poprvé dostala do parlamentu strana Švédských demokratů, vystupující proti prŕlivu přistěhovalců z islámských zemí (Historická volba..., 2010).

\section{Integrace imigrantů do školního vzdělávání}

Vzhledem k rostoucímu př́livu imigrantů musí umět vzdělávací systémy všech tř́i zemí vyrovnávat se adekvátně $\mathrm{s}$ heterogenitou žákovské populace. Základy pro úspěšnou vzdělávací dráhu dětí z rodin imigrantů a jejich pozdější zapojení do pracovního a společenského života vytváří především oblast primárního a preprimárního vzdělávání. Úspěšnost žáků ve školním vzdělávání ovlivňuje zejména znalost většinového jazyka země a socioekonomický status rodin přistěhovalců.

Významným prostředkem integrace dětí a mladistvých z rodin imigrantů je také získání školního vzdělání a profesní přípravy. Přestože formálně mají imigranti v německém vzdělávacím systému stejná práva jako Němci, ve skutečnosti nemají stejnou šanci získat stejné vzdělání jako děti a mladiství německého původu. Integraci dětí imigranti̊ mají nejvíce napomáhat $\mathrm{z}$ organizačního hlediska předškolní zařízení a celodenní školy. Zejména v Německu se zdůrazňuje, že integraci imigrantů znesnadňuje mj. nedostatečná pedagogická a odborná prríprava učitelů na práci $\mathrm{s}$ jazykově, sociálně a kulturně heterogenními žáky především jejich nedostatečná př́prava na užívání jazyka při výuce odborným předmětům. Problémem je také nedostatek učebnic a učebních materiálů (Pioch, 2004).

Ve Velké Británii neexistuje $\mathrm{v}$ současné době jednotná strategie integrace imigrantů. Vzdělávací politika považuje výchovu a vzdělávání za významný prostředek dosažení klidného soužití různorodých etnických a náboženských skupin. Imigranti mají stejné právo na předškolní vzdělávání jako místní děti.

Vláda v Anglii podporuje školy finančně při integraci imigrantů do vyučování prostřednictvím školských úruadů. Ty užívají různé strategie a formy podpory imigrantů. Např. zprostředkují žákům přijetí do škol, koordinují práci různých dobrovolných a statutárních organizací, pomáhají školám při počátečním hodnocení žáků a poskytují jim školení a poradenství a překladatelské služby. Školy zajištují imigrantům bilingvní vyučující v době, kdy jsou žáci přijímáni do školy, informují rodiče $\mathrm{v}$ jejich mateřštině o vzdělávání jejich dětí a o tom, jaké mají možnosti a práva $\mathrm{v}$ této oblasti aj. Někdy také zaměstnávají učitele se specifickou 
odpovědností za spolupráci rodiny a školy. Podobná opatření existují ve Walesu a v Severním Irsku (Integrating... 2003/04). Pro podporu imigrantů jsou využívány také dva významné granty: Grant na podporu úspěšnosti etnických minorit (Ethnic Minority Achievement Grant, EMAG) a Grant pro ohrožené děti (Vulnerable Children Grant) (Integrating... 2003/04). Britská inspekce hodnotí činnost škol mj. $\mathrm{z}$ hlediska jejich přístupu $\mathrm{k}$ imigrantům. Při všech inspekcích se sleduje, jak školy podporují rovnost příležitostí všech žáků a jejich př́istupu do škol (Office for Standards...).

Také Švédsko realizuje řadu opatření zaměřených na integraci imigrantů do škol. Týkají se i rodičů, jimž jsou poskytovány informace o možnostech vzdělávání a zajišt'ováni tlumočníci. Děti, jejichž rodiče podali žádost o povolení k pobytu ve Švédsku nebo získali toto povolení na určitou dobu, mají právo na vzdělání, současně však nemusí do školy docházet. Právo na školní vzdělání je odděleno od povinnosti (Integrace dětí ... 2004). Mnoho dětí pocházejících z rodin imigrantů využivá tzv. zařízení politiky výchovy dětí raného věku a péče o ně (Early Childhood Education and Care Policy, ECEC), určená pro malé děti, které vyžadují speciální podporu $\mathrm{v}$ rámci svého fyzického, psychického, sociálního nebo emocionálního rozvoje a $\mathrm{v}$ rámci rozvoje jazyka.

\section{Jazyková podpora imigrantů}

Jazyková podpora imigrantů se týká znalostí většinového jazyka země (vyučovacího jazyka) a mateřštiny imigrantů. Z výzkumů provedených v Německu (Migration..., 2006) vyplývá, že „k většímu pocitu vlastní hodnoty imigrantů a jejich menším psychickým problémům nevede uchování jejich mateřštiny, ale jejich jazyková asimilace“ (Ježková, von Kopp, \& Janík, 2008, s. 133). Průzkum studie PISA 2000, realizovaný v Německu, ukázal mj., že na čtenářskou kompetenci mají vliv status imigranta, sociální vrstva, z níž žák pochází, věk, kdy člověk do cizí země přišel, a jazyk, jímž se hovoří v rodině. Jazykovou podporu dětí imigrantů zajišt'ují zpravidla ministerstva školství jednotlivých spolkových zemí. Do jazykové podpory předškolních dětí z rodin imigrantů jsou zapojováni i rodiče, kteří mohou využívat i nabídek odborného poradenství. Německá vzdělávací politika na jedné straně podporuje uchování mateřštiny imigrantů, na druhé straně však často dochází k její redukci. Zásluhu na tom, že mateřština dětí přistěhovalců se stále udržuje jako vyučovací jazyk, mají často rodiče a žáci, kteří usilují o její zachování ve školách (Förderung von Migrantinnen..., 2004).

Nejčastějším modelem jazykové podpory dětí imigrantů ve všech sledovaných zemích je př́má integrace do běžných tř́d, tzv. imerze. V Německu bývá doplněna o dodatečnou podporu rozvoje němčiny jako druhého jazyka. ${ }^{1}$ Integrovanou výuku může dále doplňovat dobrovolná návštěva hodin mateřského jazyka imigrantů.

Mladí lidé, kteří přijeli do Spojeného království v posledních dvou letech povinné školní docházky a mají minimální nebo žádnou znalost angličtiny, a v některých př́ípadech dokonce malou nebo žádnou předchozí zkušenost se vzděláváním, jsou považováni za žáky se zvláštními potřebami. Vláda finančně podporuje výuku angličtině pro osoby hovořici jinými jazyky (English for Speakers Other Languages, ESOL). Avšak mnoho imigrantů, kteří se chtějí učit angličtině, nemůže, protože poptávka převyšuje nabídku a je dlouhá čekací doba (Community cohesion..., 2007/08). Žáci nemají nárok na výuku své mateřštině. Děti s jinou

\footnotetext{
${ }^{1}$ Druhý jazyk je jazyk, jímž člověk hovoří vedle své mateřštiny a který potřebuje ve svém každodenním životě. Liší se tak od cizího jazyka, který člověk běžně neužívá. Také ve školách se rozlišuje výuka druhému jazyku a cizímu jazyku.
} 
mateřštinou než angličtinou získávají $\mathrm{v}$ př́ípadě nezbytnosti dodatečnou jazykovou podporu (Integrating..., 2003/04).

Švédská legislativa reagovala vstřícně na př́liv imigrantů do země, zejména v oblasti zajišsění výuky jazykům pro př́islušníky etnických menšin. Již v roce 1975 schválil švédský parlament Zákon o imigrantech a menšinách, jímž dává všem dětem právo na vzdělávání $\mathrm{v}$ jejich mateřštině. $\mathrm{V}$ rámci podpůrných opatření je zajišt'ována nejprve výuka švédštině. Přistěhovalci ve věku povinné školní docházky mají oficiálně právo na výuku mateřskému jazyku, pokud o ni projeví zájem (Gunarson, Korpi, \& Nordenstam, 1999). V některých obcích je organizována pro děti přistěhovalců na úrovni preprimárního vzdělávání výuka základům vyučovacího jazyka, jejímž cílem je připravit je na přechod na úroveň povinného vzdělávání. Kvưli př́livu imigrantů byl zaveden pro dospělé imigranty starší 16 let program Švédština pro imigranty (Swedish for immigrants, SFI).

\section{Shrnutí}

Mezi sledovanými zeměmi jsme nezaznamenali žádné zásadní rozdíly. Všechny země se stávají vlivem př́livu imigrantů stále více multikulturními. Hlavním prostředkem integrace imigrantů do školy a společnosti je podpora znalosti většinového jazyka země. Významnou roli hraje příprava dětí na školu a primární vzdělávání. Vliv socioekonomického zázemí žáků na jejich úspěšnost ve škole se projevuje v Německu nejvíce u imigrantů. Ve Velké Británii a Švédsku bývají považovány děti imigrantů za děti vyžadující speciální podporu. Existuje řada opatření zaměřených na jejich integraci do škol na všech úrovních školního vzdělávání. V Německu se poukazuje na rozdíl mezi cíli vzdělávací politiky v oblasti integrace imigrantů a jejím uskutečňováním v praxi. Jazyková podpora imigrantů probíhá také formou CLIL obsahově a jazykově integrovaného učení, a to zejména ve Švédsku a částečně v Německu. Bilingvní modely vyučování jsou obecně spojeny s velkými finančními náklady, nebot' je třeba mnoho kompetentních bilingvních učitelů, schopných vyučovat předměty ve všech ročnících základních i vyšších sekundárních škol v jiném jazyce než ve své mateřštině.

\section{Literatura}

Community cohesion and migration. Tenth report of session 2007-08. (2008). Dostupné z www.publications.parliament.uk

Förderung von migrantinnen und migranten in der sekundarstufe I. (2004). Berlin und Bonn: Beauftragte der Bundesregierung für Migration, Flüchtlinge und Integration.

Gunarson, L., Korpi, B. M., \& Nordenstam, B. (1999). Early childhood education and care policy in Sweden. Regeringskasliet. Dostupné z http://www.oecd.org/dataoecd/9/35/1915135.pdf

Historická volba Švédũ: Triumf pravice, zdar extremistů. (2010). Dostupné z http://aktualne.centrum.cz/zahranici/evropa/

Integrace děti přistěhovalcủ do škol v Evropě. (2004). Eurydice.

Integrating immigrant children into schools in Europe. United Kingdom (England, Wales and Northern Ireland). National Description - 2003/04. European Commission. Dostupné $\mathrm{z}$ www.eurydice.org/ressources

Ježková, V., von Kopp, B., \& Janík, T. (2008). Školní vzdělávání v Německu. Praha: Karolinum. Migration, sprache und integration. AKI-Forschungsbilanz 4. (2006). Wissenschaftszentrum Berlin für Sozialforschung (WZB). Dostupné z

www.wz-berlin.de/zkd/aki/files/AKI-Forschungsbilanz_4.pdf 
Office for standards in education, children's services and skills. Dostupné z http://www.ofsted.gov.uk/Ofsted-home/About-us

Pioch, U. (2004). Innovative Ansätze im Unterricht. In Förderung von migrantinnen und migranten in der sekundarstufe I. Fachtagung am 3. Dezember 2003 in Berlin (pp. 70-74). Berlin und Bonn: Beauftragte der Bundesregierung für Migration, Flüchtlinge und Integration.

Protiimigračni strana se hlási ke slovu i ve Švédsku. (2010). Dostupné z http://aktualne.centrum.cz/zahranici/evropa/

Statistisches Bundesamt Deutschland. Dostupné z http://www.destatis.de/jetspeed/portal/cms/

Swedish for immigrants, Sfi. (2009). Skolverket. Dostupné z http://www3.skolverket.se/ki03/info.aspx?infotyp

Švédsko si neví rady s rostoucím př́ilivem běženců. Severské listy, 17. května 2010. Dostupné z http://www.severskelisty.cz/kaleido/kale0048.htm

\section{Kontakt}

PaedDr. Věra Ježková, Ph.D.

Karlova univerzita v Praze

Pedagogická fakulta, Ústav výzkumu a rozvoje vzdělávání

Myslíkova 7, 11000 Praha 1

e-mail: vera.jezkova@pedf.cuni.cz

\section{Bibliografické údaje}

Ježková, V. (2011). Imigranti ve školním vzdělávání v Německu, Velké Británii a Švédsku. In T. Janík, P. Knecht, \& S. Šebestová (Eds.), Smíšený design v pedagogickém výzkumu: Sborník přispěvki̊ z 19. výročni konference České asociace pedagogického výzkumu (s. 328-332). Brno: Masarykova univerzita.

Dostupné z: http://www.ped.muni.cz/capv2011/sbornikprispevku/jezkova.pdf

doi: 10.5817/PdF.P210-CAPV-2012-17 